\title{
Gas Chromatography-mass spectrometry Analysis of Methanol Extracts from Marine Red Seaweed Gracilaria corticata
}

\author{
Venkataraghavan Ragunathan, Jayashree Pandurangan, Thiruchelvi Ramakrishnan*
}

Venkataraghavan Ragunathan, Jayashree Pandurangan, Thiruchelvi Ramakrishnan*

Department of Bio-Engineering, School of Engineering, Vels Institute of Science, Technology and Advanced Studies, Chennai-600117, Tamil Nadu, INDIA.

Correspondence

Mrs. Thiruchelvi Ramakrishnan

Department of Bio-Engineering, School of Engineering, Vels Institute of Science, Technology and Advanced Studies, Chennai- 600117, Tamil Nadu, INDIA.

Phone no : +00-91-7550057190

E-mail: thiruchelvi.se@velsuniv.ac.in

\section{History}

- Submission Date: 26-12-2018;

- Review completed: 28-01-2019;

- Accepted Date: 11-04-2019

DOI : 10.5530/pj.2019.11.87

Article Available online

http://www.phcogj.com/v11/i3

\section{Copyright}

(c) 2019 Pharmacognosy Journal. This is an open-access article distributed under the terms of the Creative Commons Attribution 4.0 International license.

\begin{abstract}
Introduction: The objective of the work is to analyse the methanol extract of marine red macro algae species Gracilaria corticata using Gas chromatography-Mass spectrometry (GC-MS) to reveal the presence of various secondary metabolites and bioactive compounds present in the algae and study its diverse properties. Methods: Gracilaria corticata was collected along the shore of Mandapam and was identified and authenticated. The methanol extract of the algae was prepared and analysed using GC-MS Perkin-Elmer, Clarus 680 model to reveal the various bioactive present in the algae. Results: The analysis revealed several bioactive compounds:undecane; 2-decyloxirane (2.023\%); Methy n-tridecanoate; n-hexadecanoic acid (74.198\%); eicosanoic acid (2.262\%); nonanoic acid $(2.084 \%)$; oleic acid $(6.609 \%)$; oleic acid (4.156\%); pentadecanoic acid (2.176\%); bicycle [3.2.1] oct-3-en-2-one,3,8-dihydroxy1-1methoxy-7-(7-methoxy-1, 3 benzodioxol-5-yl)-6-methyl-5 (2.901\%);N-(5-chloro-2-hydroxyphenyl) dodecanamide (2.048\%); and cholesta-8,24-dien-3-ol,4-methyl (1.542\%). The bioactive compounds from methanol extract of algae after GC-MS analysis and their essential medicinal properties were studied in this research work. Conclusion: Gracilaria corticata has potential against bacteria, fungi, free radical scavenging, etc and can used in the drug discovery and development sector.

Key words: Gracilaria corticata, Bioactive compounds, GC-MS, Medicinal properties, Secondary metabolites.
\end{abstract}

\section{INTRODUCTION}

The marine ecosystem is a home for nearly $80 \%$ of the world's animal and plant species. ${ }^{1}$ Approximately 150,000 species of seaweeds are found along the intertidal zone. The seaweeds are a rich source of various natural products and find an important place in the pharmaceutical, cosmetics and drug development industries. ${ }^{2}$ Seaweeds occur in areas of seashore such as coastal areas of Mandapam, Ramanathapuram district. Seaweeds grow in the shallow waters in the intertidal zones of the marine ecosystem. The seaweeds possess the unique feature that promote their survival in the salty marine ecosystem. The osmolarity in their cytoplasm is adjusted with respect to the osmolarity of the salty sea water. This adaptation does not allow the desiccation to take place. The seaweeds lack true leaves, stems and roots. They have modified stems, roots and leaves to sustain in the marine ecosystem. ${ }^{3}$

Seaweeds are one of the predominant and promising sources of various bioactive secondary metabolites. Their discovery has augmented in the past few decades. ${ }^{4}$ Their discovery is essential for mankind. They are a good source of proteins, carbohydrates, minerals, vitamins, polysaccharides and steroids. They are used as a predominant protein rich-food for the scientists working at International space station. ${ }^{4}$ The brown and red macroalgae are used against hyperthyroidism. ${ }^{5-6}$ Gracilaria corticata alcoholic extracts have shown potential against AIDS. ${ }^{7}$ The poly-unsaturated lipids are used for the treatment of diverse cardiovascular pathogens. ${ }^{8}$ Gracilaria corticata synthesize a diverse variety of essential compounds such asxanthophylls, chlorophylls, proteins, minerals, vitamins, carrageenan, alginate, agar, fucoidan, laminarin, galactosyl glycerol, proteoglycans, amino acids, poly-unsaturated fatty acids and antioxidants like polyphenols, terpenoids, halogens and alkaloids. ${ }^{9-19}$ In-vivo studies on the toxicity of Gracilaria corticata was studied on mice models and were reported to be non-toxic. ${ }^{8}$

Studies on Gracilaria corticata and their phytochemicals, bioactive compounds and medicinal properties are less revealed when compared to other species of Gracilaria. Therefore, this research work illuminates on the various bioactive compounds and their properties from GC-MS analysis of Gracilaria corticata.

\section{MATERIALS AND METHODS}

\section{Collection of algae}

The Gracilaria corticata was collected from the intertidal shallow zone of Mandapam, Ramanatha-
Cite this article: Ragunathan V, Pandurangan J, Ramakrishnan T. Gas Chromatography-Mass spectrometry Analysis of Methanol Extracts from Marine Red Seaweed Gracilaria corticata. Pharmacog J. 2019;11(3):547-54. 
puram district. The algae were obtained from the coat of Mandapam (Lat.: $9^{\circ} 16^{\prime} 32.56^{\prime \prime} \mathrm{N}$ and Lon.: $79^{\circ} 7^{\prime} 25.03^{\prime \prime} \mathrm{E}$ ) along the southern regions of Tamilnadu. The harvested algae were washed with water to remove sand particles and epiphytes and packed in a polythene bag and was brought to the laboratory. The algae were further washed with distilled water to remove traces of salts and other contaminants, shade dried and stored.

\section{Authentication of algae}

The collected algae were authenticated by Dr. M. Ganesan, Senior Scientist, CSIR- Central Salt Marine Chemical Research Institute (CSIR-CSMCRI), Ramanathapuram district, Tamilnadu, India. The algae were identified as Gracilaria corticata and were used for the research work.

\section{Preparation of powder and extract}

The shade dried algae were crushed to small pieces using mortar and pestle and further powdered using an electric blender. The extract of was prepared by adding $2 \mathrm{~g}$ of the powdered algae sample with $20 \mathrm{ml}$ of methanol. The mixture was then incubated overnight in an orbital shaker at $32^{\circ} \mathrm{C}$. The extract was then filtered using No.1 Whatmann filter paper and a funnel. The extract was collected in a $100 \mathrm{~mL}$ conical flask. The collected extract was dried using a rotary vacuum evaporator to evaporate the solvent to obtain the crude extract of the algae. The collected extract was then used for GC-MS analysis.

\section{Gas Chromatography-mass Spectrometry (GC-MS) analysis of Gracilaria corticata}

The methanolic extract of Gracilaria corticata was subjected to GC-MS analysis. The analysis was performed in Sophisticated Instrumentation Facility (SIF), Chemistry Division for NMR and GC-MS Analysis, Vellore Institute of Technology, Vellore. The GC-MS analysis was performed using the Perkin-Elmer, Clarus 680 model using Clarus 600 (Electron Ionization) as the source for ionization.

\section{GC-MS analysis}

The Clarus 680 equipped with fused silica column packed with Elite-5MS ( $5 \%$ biphenyl 95\% dimethyl polysiloxane, $30 \mathrm{~m} \times 0.25 \mathrm{~mm} \mathrm{ID} \times 250 \mu \mathrm{m} \mathrm{df}$ ) was used. The active components were separated using the inert gas helium as carrier gas at the flow rate of $1 \mathrm{~mL} / \mathrm{min}$. The injector temperature was set at $260^{\circ} \mathrm{C}$ during the run. One $\mu \mathrm{L}$ of the sample extract (Gracilaria methanol extract) was injected into the GC-MS instrument and the oven temperature set were as follows: $60^{\circ} \mathrm{C}$ for $2 \mathrm{~min}$; followed by $300^{\circ} \mathrm{C}$ at the rate of $10^{\circ} \mathrm{C}$ per min; and held for 6 mins at temperature of $300^{\circ} \mathrm{C}$. The mass detector process was as follows: transfer line temperature of $240^{\circ} \mathrm{C}$; ion source temperature of $240^{\circ} \mathrm{C}$ and $70 \mathrm{eV}$ of electron ionization impact. The scan interval of $0.1 \mathrm{sec}$ and a scan time of 0.2 secs with a scan range of 50 to 600 Daltons were set. The spectrum for the GC-MS analysis was obtained using the Turbo Massver 5.4.2 software and was compared with the National institute of standards and technology-2008 (NIST-2008) standard library database.

\section{RESULTS AND DISCUSSION}

A total of thirteen bioactive compounds were obtained from the peaks of methanolic extracts of Gracilaria corticata by GC-MS analysis. The details of the bioactive compounds were tabulated (Table 1). Figure 1 shows the chromatogram of the compounds detected using GC-MS. Out of thirteen compounds, only ten compounds were detected as major peaks in the chromatogram with their retention time and peak area (Figure 2 to 12). The mass spectra of the compounds were compared with the standard library data bases and were characterized and identified.

There were three compounds whose peaks were too small to be detected in the chromatogram (Figure 13 to 15), the table below give the details of the predicted compounds with their retention time, the peak area for the compounds were not calculated but were analysed and predicted through mass spectrum (Table 2).

The Table 3 represent the ten bioactive compounds from methanol extracts of Gracilaria corticata with their structure, molecular formula and molecular weight with high peak areas and intensities.

Table 4 denotes the diverse properties of all the bioactive compounds detected using GC-MS.

Phytochemicals are secondary metabolites from plants that are essential for the plant defence against grazing animals and other predators. The secondary metabolites are those that are not directly involved in the growth of the plant, instead they constitute a vital protection and resistance. The methanol extract of Gracilaria corticata after GC-MS analysis showed several bioactive compounds including fatty acids like n-hexadecanoic acid, eicosanoic acid, nonanoic acid, oleic acid and

Table 1: Details of Phytochemicals Identified through GC-MS Analysis of Methanol Extract.

\begin{tabular}{|c|c|c|c|c|c|c|c|}
\hline Peak & $\begin{array}{l}\text { Retention } \\
\text { time ( } \mathrm{min})\end{array}$ & Name of the compound & Scan & Height & $\begin{array}{c}\text { Area } \\
\text { (Intensity*sec) }\end{array}$ & Area (\%) & Norm \% \\
\hline 1 & 17.345 & Oxirane, decyl- & 2908 & $21,133,272$ & $2,632,621.2$ & 2.023 & 2.73 \\
\hline 2 & 18.795 & n-hexadecanoic acid & 3198 & $128,331,784$ & $96,576,664.0$ & 74.198 & 100.00 \\
\hline 3 & 20.126 & Eicosanoic acid & 3464 & $24,689,006$ & $2,944,463.2$ & 2.262 & 3.05 \\
\hline 4 & 20.306 & Nonanoic acid & 3500 & $20,235,054$ & $2,713,160.8$ & 2.084 & 2.81 \\
\hline 5 & 20.716 & Oleic acid & 3582 & $24,858,102$ & $8,602,715.0$ & 6.609 & 8.91 \\
\hline 7 & 21.731 & Pentadecanoic acid & 3785 & $12,568,093$ & $2,832,692.0$ & 2.176 & 2.93 \\
\hline 8 & 22.862 & $\begin{array}{l}\text { Bicyclo[3.2.1]oct-3-en-2-one, 3,8-dihydroxy-1-methoxy-7- } \\
\text { (7-methoxy-1,3-benzodioxol-5-yl)-6-methyl-5 }\end{array}$ & 4011 & $18,728,876$ & $3,775,650.5$ & 2.901 & 3.91 \\
\hline 9 & 25.373 & $\mathrm{~N}$-(5-chloro-2-hydroxyphenyl)dodecanamide & 4513 & $15,933,098$ & $2,665,857.5$ & 2.048 & 2.76 \\
\hline 10 & 27.294 & Cholesta-8,24-dien-3-ol, 4-methyl-, (3.beta.,4.alpha.)- & 4897 & $10,175,952$ & $2,007,103.9$ & 1.542 & 2.08 \\
\hline
\end{tabular}

Min: minute, sec: second, Da: Daltons.

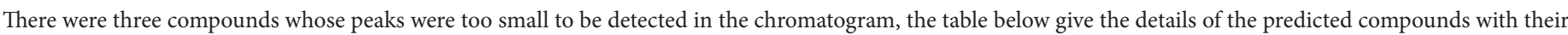
retention time, the peak area for the compounds were not calculated but were analysed and predicted through mass spectrum. 
Table 2: Details of Compounds Identified through GC-MS without Peak Area.

\begin{tabular}{|c|c|c|c|c|c|}
\hline Peak & Retention time (min) & Name of the compound & Structure & Molecular formula & Molecular weight (Da) \\
\hline 1 & 15.899 & 2-methyl, Undecane & & $\mathrm{C}_{12} \mathrm{H}_{26}$ & 170 \\
\hline 2 & 16.939 & Hexadecanal & & $\mathrm{C}_{16} \mathrm{H}_{32} \mathrm{O}$ & 240 \\
\hline 3 & 18.030 & $\begin{array}{l}\text { Triacontanoic acid, } \\
\text { methyl ester }\end{array}$ & & $\mathrm{C}_{31} \mathrm{H}_{62} \mathrm{O}_{2}$ & 466 \\
\hline
\end{tabular}

The table represent the methanolic extracts of ten bioactive compounds from Gracilaria corticata with their structure, molecular formula and molecular weightwith high peak areas and intensities.

Table 3: Essential Details of Phytochemicals from Methanol Extract.

\begin{tabular}{|c|c|c|c|c|}
\hline S. No & Name of the compound & Structure & $\begin{array}{l}\text { Molecular } \\
\text { formula }\end{array}$ & $\begin{array}{l}\text { Molecular weight } \\
\text { (Da) }\end{array}$ \\
\hline 1 & Oxirane, decyl- & & $\mathrm{C}_{12} \mathrm{H}_{24} \mathrm{O}$ & 184.32 \\
\hline 2 & n-hexadecanoic acid & & $\mathrm{C}_{16} \mathrm{H}_{32} \mathrm{O}_{2}$ & 256.43 \\
\hline 3 & Eicosanoic acid & & $\mathrm{C}_{20} \mathrm{H}_{40} \mathrm{O}_{2}$ & 312.53 \\
\hline 4 & Nonanoic acid & & $\mathrm{C}_{9} \mathrm{H}_{18} \mathrm{O}_{2}$ & 158.23 \\
\hline 5 & Oleic acid & & $\mathrm{C}_{18} \mathrm{H}_{34} \mathrm{O}_{2}$ & 282.47 \\
\hline 6 & Oleic acid & & $\mathrm{C}_{18} \mathrm{H}_{34} \mathrm{O} 2$ & 282.47 \\
\hline 7 & Pentadecanoic acid & & $\mathrm{C}_{15} \mathrm{H}_{30} \mathrm{O}_{2}$ & 242.39 \\
\hline 8 & $\begin{array}{l}\text { Bicyclo[3.2.1]oct-3-en-2-one, 3,8-dihydroxy- } \\
\text { 1-methoxy-7-(7-methoxy-1,3-benzodioxol-5- } \\
\text { yl)-6-methyl-5 }\end{array}$ & & $\mathrm{C}_{21} \mathrm{H}_{24} \mathrm{O}_{7}$ & 388.41 \\
\hline 9 & N-(5-chloro-2-hydroxyphenyl)dodecanamide & & $\mathrm{C}_{18} \mathrm{H}_{28} \mathrm{ClNO}_{2}$ & 325.87 \\
\hline 10 & $\begin{array}{l}\text { Cholesta-8,24-dien-3-ol, 4-methyl-, (3.beta.,4. } \\
\text { alpha.)- }\end{array}$ & & $\mathrm{C}_{28} \mathrm{H}_{46} \mathrm{O}$ & 398.00 \\
\hline
\end{tabular}




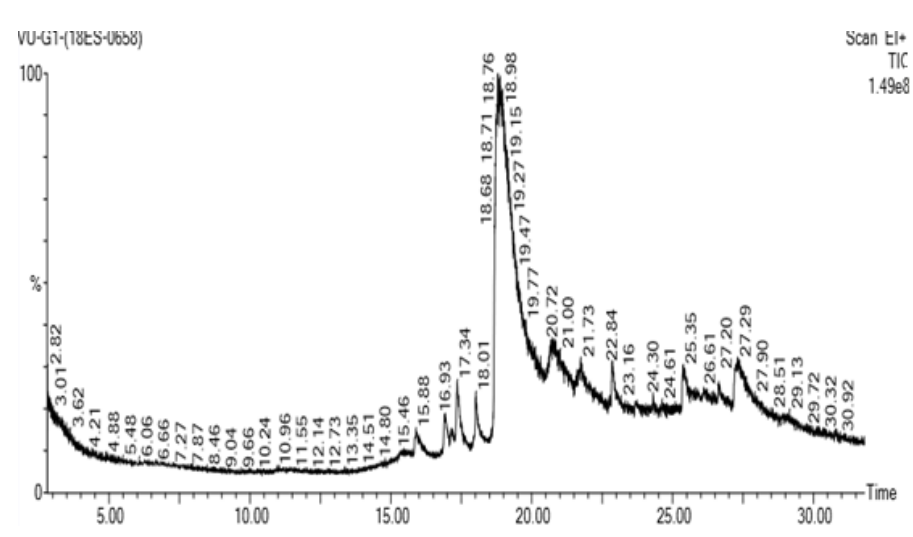

Figure 1: Qualitative report of GC-MS analysis (Area \% vs Retention time) of methanol extract of Gracilaria corticata.

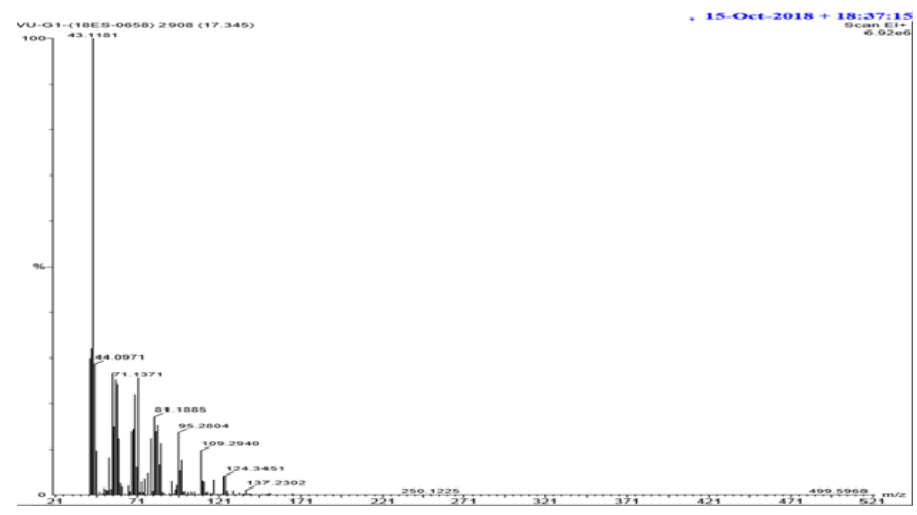

Figure 3: Spectrum of Oxirane, decyl-.

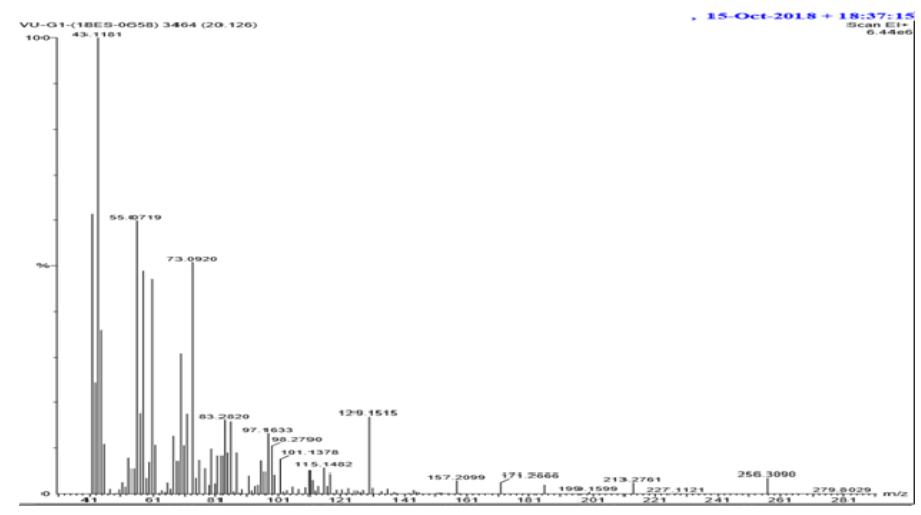

Figure 5: Spectrum of eicosanoic acid.

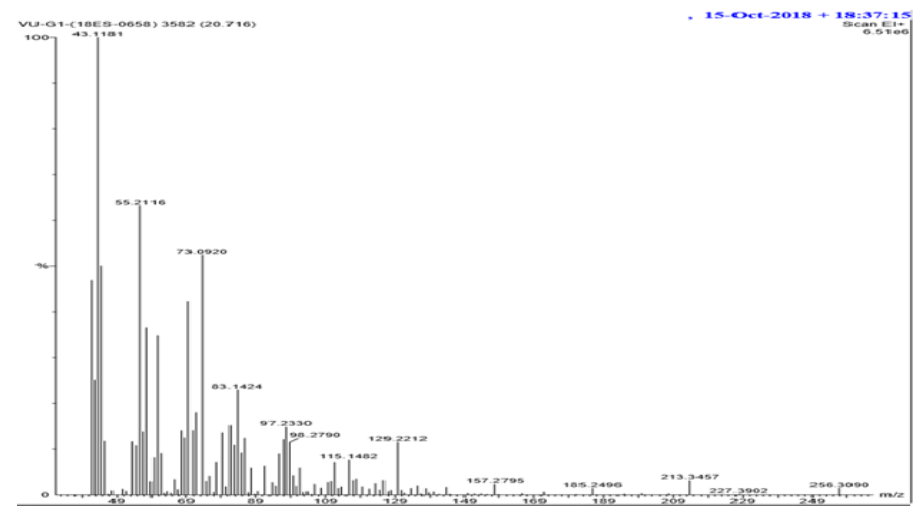

Figure 7: Spectrum of oleic acid.

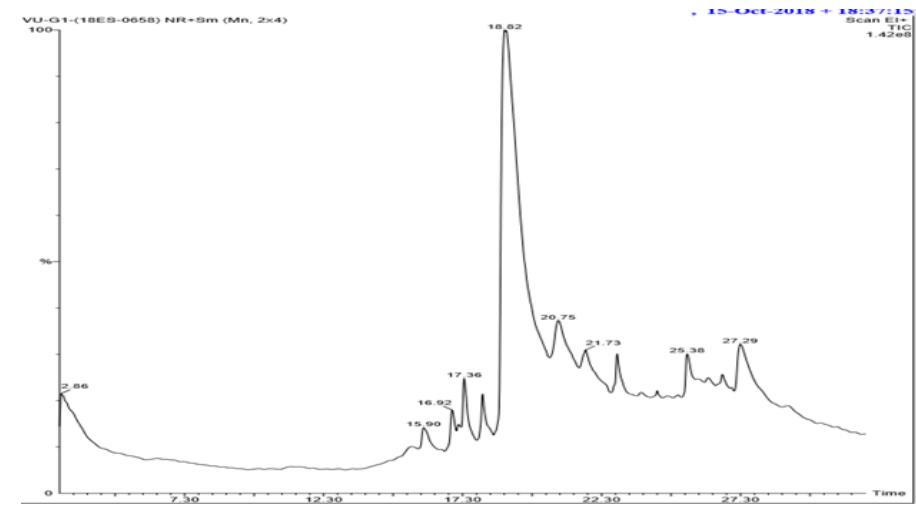

Figure 2: Chromatogram of methanol extract of Gracilaria corticata.

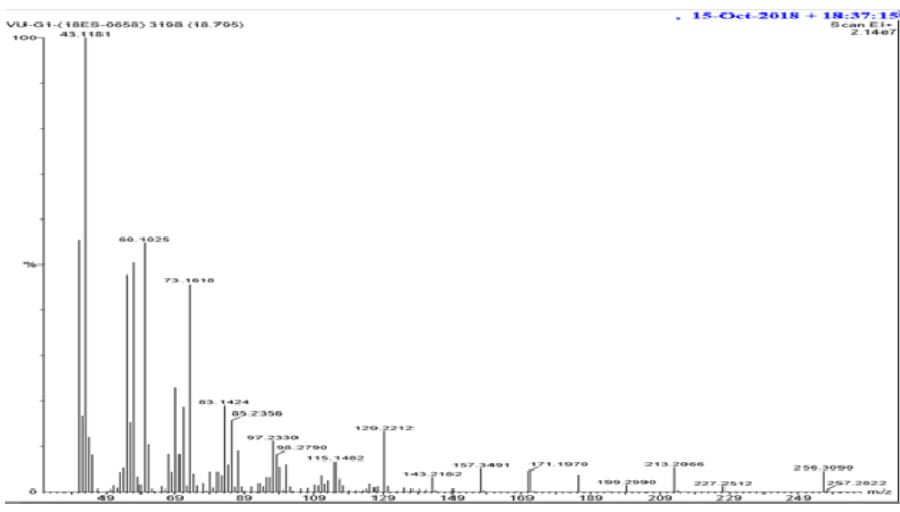

Figure 4: Spectrum of $n$-hexadecanoic acid.

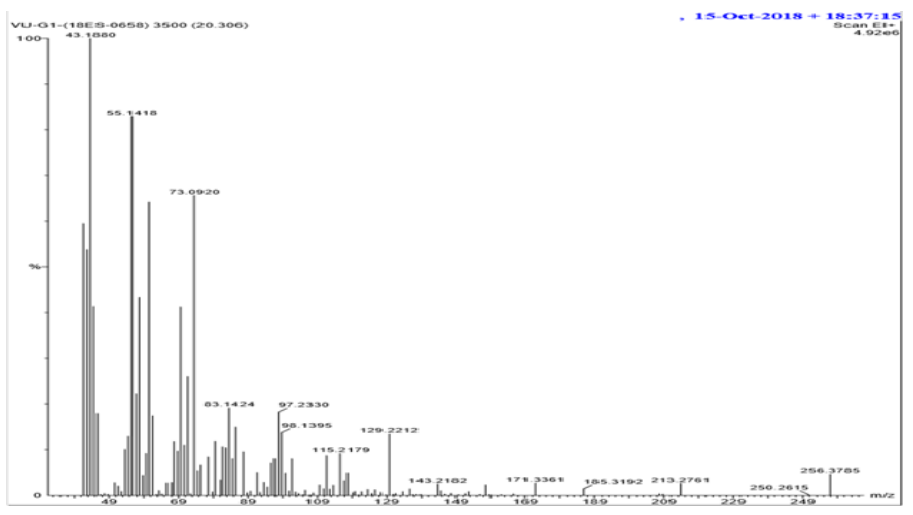

Figure 6: Spectrum of nonanoic acid.

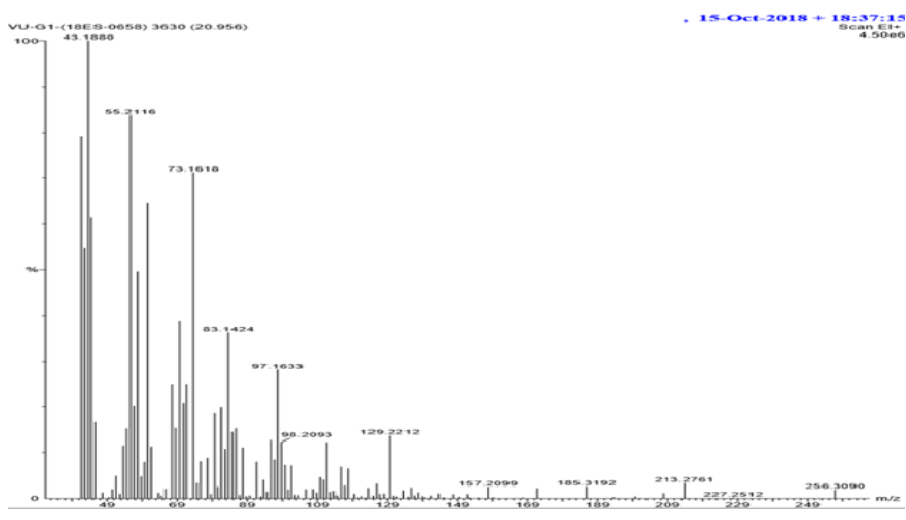

Figure 8: Spectrum of oleic acid. 


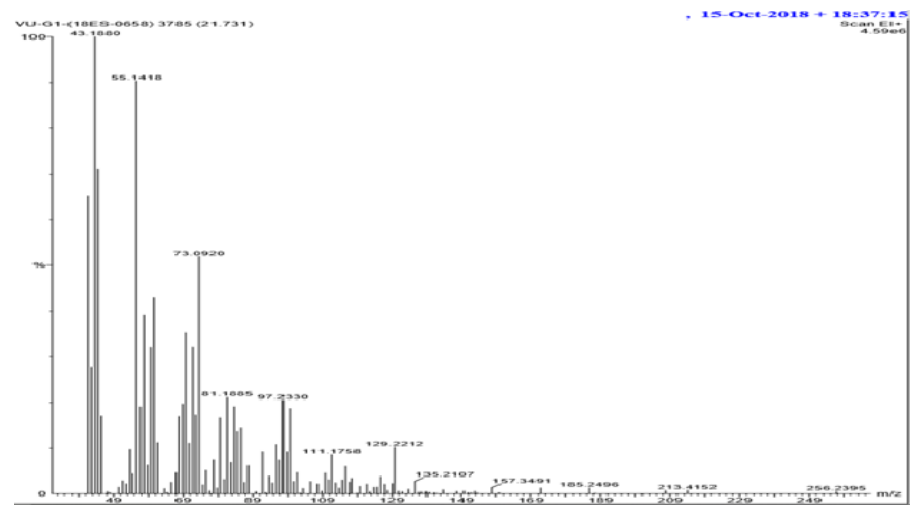

Figure 9: Spectrum of pentadecanoic acid.

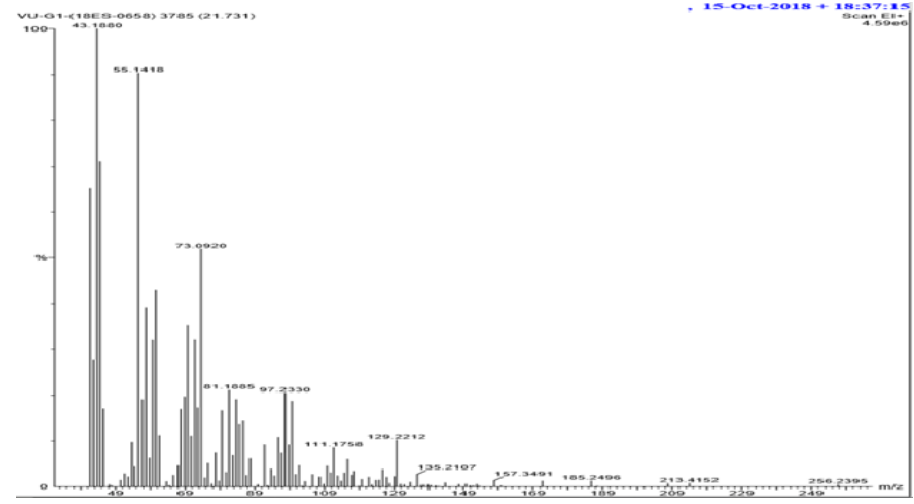

Figure 11: Spectrum of $\mathrm{N}$-(5-chloro-2-hydroxyphenyl) dodecanamide.

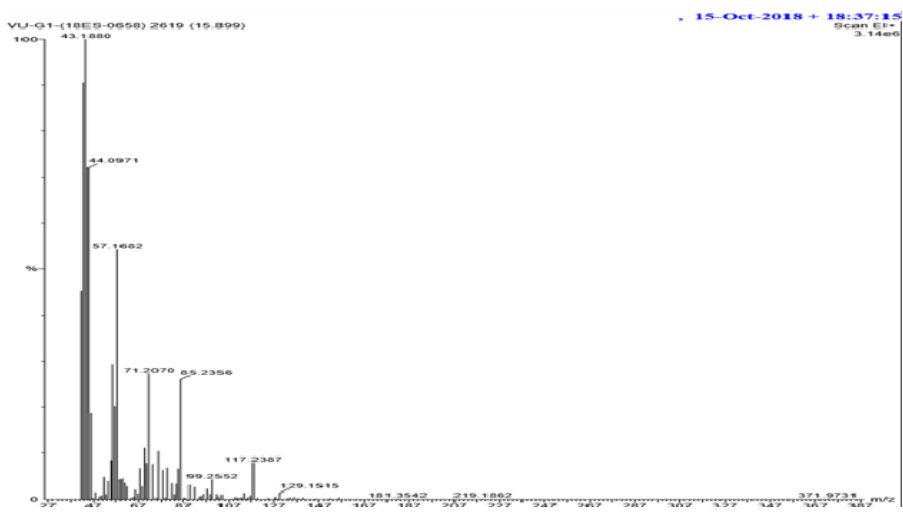

Figure 13: Spectrum of undecane, 2-methyl-.

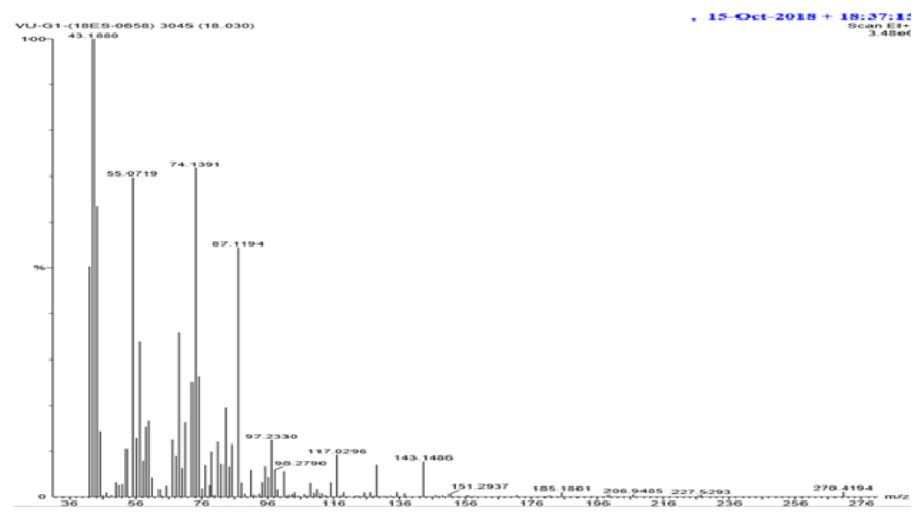

Figure 15: Spectrum of triacontanoic acid, methyl ester.

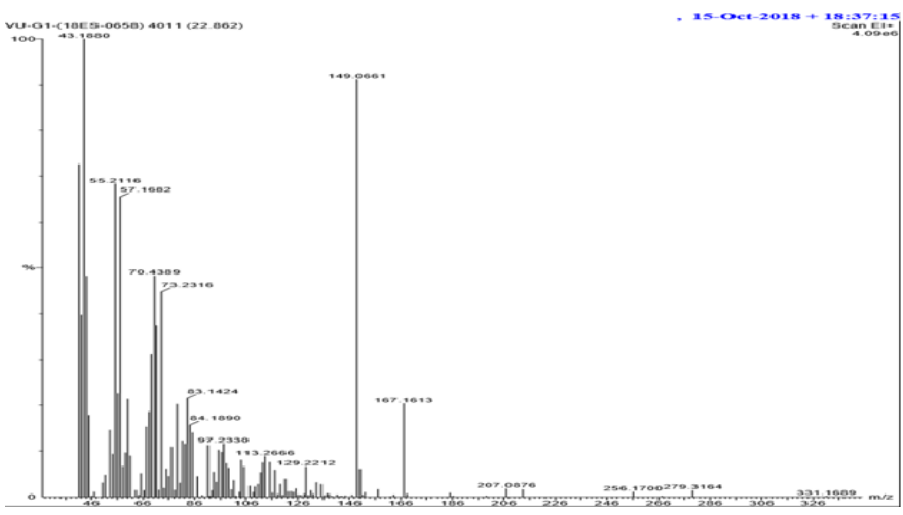

Figure 10: Spectrum of Bicyclo[3.2.1]oct-3-en-2-one, 3,8-dihydroxy-1-methoxy-7-(7-methoxy-1,3-benzodioxol-5-yl)-6-methyl-5.

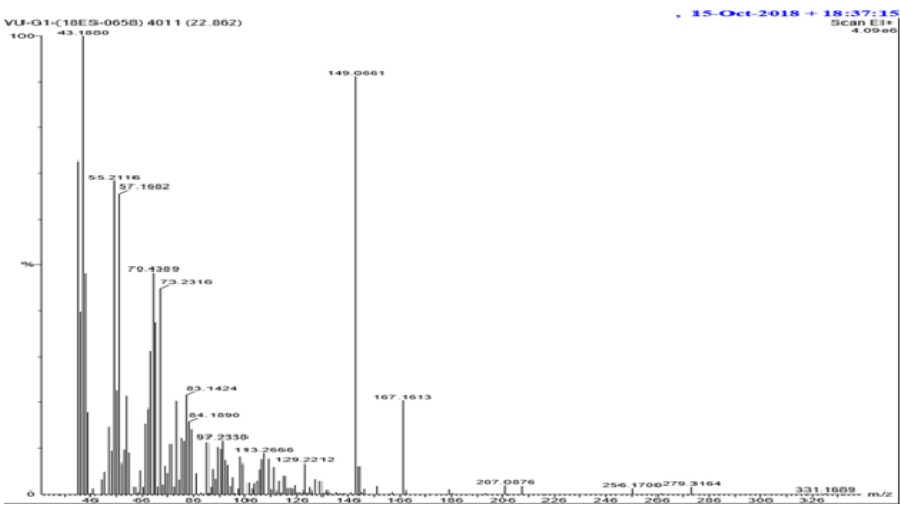

Figure 12: Spectrum of Cholesta-8,24-dien-3-ol, 4-methyl-, (3.beta.,4.alpha)-.

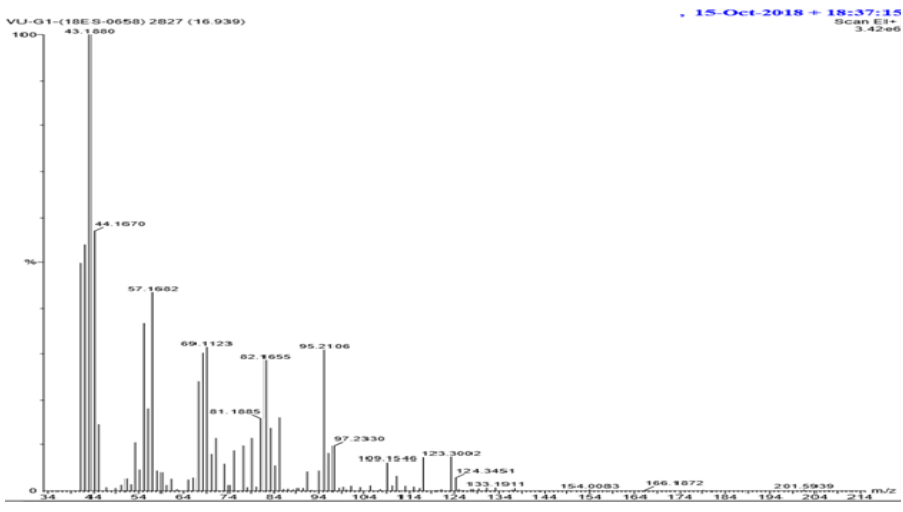

Figure 14: Spectrum of hexadecanal.

pentadecanoic acid that have reported to possess high antibacterial, antifungal and antioxidant properties (Sermakkani and Thangapandian, 2012; Elizabeth and Arumugam, 2014). ${ }^{20-28}$ Methyl esters such as n-hexadecanoic acid (Palmitic acid), eicosanoic acid (Arachidic acid), oleic acid and pentadecanoic acid have shown potential to inhibit various bacterial pathogensand polymorphic fungal species such as Bacillus pumilis, Escherichia coli, Micrococcus luteus, Klebsiella pneumoniae, Staphylococcusaureus, Pseudomonas aeruginosa, Candida albicans, candida tropicalis and Candida krusei. ${ }^{33}$ Candida albicansis a pathogenic fungal strain that causes various life-threatening skin infections, candidiasis and oral infections ${ }^{34}$ were inhibited by methyl esters. Free saturated fatty acids like n-hexadecanoic acid, eicosanoic acid, oleic acid and pentadecanoic acid have shown immense potential to inhibit the growth of grampositive bacteria such as Streptococcus mutans and polymorphic fungi 
Table 4: Activity of phytochemicals from methanol extracts of Gracilaria corticata

\begin{tabular}{|c|c|c|c|c|}
\hline S.No & Name of the compound & Reference & $\begin{array}{l}\text { Reference } \\
\text { number }\end{array}$ & Property \\
\hline 1 & Oxirane, decyl- & - & - & - \\
\hline 2 & n-hexadecanoic acid & $\begin{array}{l}\text { Sermakkani et al., 2012; Elezabeth et al., } \\
\text { 2014; Zheng et al., } 2005\end{array}$ & $20-22$ & $\begin{array}{l}\text { Preservative, antioxidant, } \\
\text { nematicide, pesticide, } \\
\text { lubricant, antipsychotic, } \\
\text { antiandrogenic }\end{array}$ \\
\hline 3 & Eicosanoic acid & Pinto et al., 2017; Sahin et al., 2006 & 23,24 & $\begin{array}{l}\text { Antibacterial, antifungal, } \\
\text { antioxidant }\end{array}$ \\
\hline 4 & Nonanoic acid & ORHAN et al., 2011 & 25 & Antibacterial \\
\hline 5 & Oleic acid & $\begin{array}{l}\text { Walter et al., 2004; El-Din and El-Ahwany, } \\
\text { 2016; Liu et al., } 2017\end{array}$ & $26-28$ & $\begin{array}{l}\text { Antibacterial, antiviral, } \\
\text { antioxidant, antifungal }\end{array}$ \\
\hline 6 & Oleic acid & $\begin{array}{l}\text { Walter et al., 2004; El-Din and El-Ahwany, } \\
\text { 2016; Liu et al., } 2017\end{array}$ & $26-28$ & $\begin{array}{l}\text { Antibacterial, antiviral, } \\
\text { antioxidant, antifungal }\end{array}$ \\
\hline 7 & Pentadecanoic acid & Liu et al., 2017 & 28 & Antioxidant \\
\hline 8 & $\begin{array}{l}\text { Bicyclo[3.2.1]oct-3-en-2-one, 3,8-dihydroxy-1- } \\
\text { methoxy-7-(7-methoxy-1,3-benzodioxol-5-yl)- } \\
\text { 6-methyl-5 }\end{array}$ & Geethalakshmi et al., 2013 & 29 & Antifungal, antiparasitic \\
\hline 9 & N-(5-chloro-2-hydroxyphenyl) dodecanamide & - & - & - \\
\hline 10 & $\begin{array}{l}\text { Cholesta-8,24-dien-3-ol, 4-methyl-, (3.beta.,4. } \\
\text { alpha.)- }\end{array}$ & - & - & - \\
\hline 11 & Undecane, 2-methyl- & Iauk et al., 2015 & 30 & Antimicrobial \\
\hline 12 & Hexadecanal & Kumar et al., 2015 & 31 & Antibacterial, antioxidant \\
\hline 13 & Triacontanoic acid, methyl ester & Sermakkani and Thangapandian, 2012 & 32 & Antibacterial \\
\hline
\end{tabular}

Candida albicans that are an important causative agent for oral infections such as dental caries, gingivitis and periodontitis in humans. These studies were performed in-vitro through MIC studies. ${ }^{35}$ Fortunately, the fatty acids have shown to inhibit the methicillin-resistant Staphylococcus aureus, Helicobacter pyroli and Candida albicans. ${ }^{36-37}$ The fatty acids have shown potential to inhibit without any side effects. Bicyclo[3.2.1]oct3-en-2-one, 3,8-dihydroxy-1-methoxy-7-(7-methoxy-1,3-benzodioxol5-yl)-6-methyl-5 also known as medioresinol has shown inhibition against leishmanias is by producing Reactive Oxygen Species (ROS) and free radicals and causing the death of the parasite. Medioresinol also has antifungal property. The endophytic fungi Candida albicans responsible for skin and oral infections were killed. ${ }^{38}$ The medioresinol acts by producing reactive oxygen species inside the cell and inhibit the cell cycle regulation and increase the chance for apoptosis. Medioresinol induces the ROS resulting in the increased oxidative stress inside the cell and ultimately leading the mitochondrial dysfunction and activating the pro-apoptotic factors. The pro-apoptotic factor proteins like BAK and BAX causes pores in the mitochondria resulting in the release of cytochrome $\mathrm{c}$ and cause apoptosis. This results in the DNA fragmentation causing the lysis of the fungi. ${ }^{38}$ Hexadecanal, also known as palmitaldehyde have shown to resist the growth of pathogenic microorganisms such as Staphylococcus aureus, Bacillus subtilis and Pseudomonas aeruginosa. Ethyl acetate root extract of the plant Dorema ammoniacum contained high levels of hexadecanal and also has antioxidant properties in both the DPPH and FRAP assays. ${ }^{39}$

\section{CONCLUSION}

Marine seaweed Gracilaria corticata has several immense properties against pathogenic bacteria, fungi, viruses and parasites. The presence of essential bioactive compounds from the algae are responsible for these properties. Novel antimicrobial cream and pharmaceutical products are developed day to day using this species. The algae possess antioxidant potential in the free radicals scavenging. The presence of diverse essential components such as amino acids, polysaccharides, vitamins, minerals, carrageenan makes them more suitable to be included in the diet. The presence of carrageenan, sulphated polysaccharides and agar make them to find a spot in the cosmetics and food industries. The presence of pigments such as phycoerythrin and phycocyanin are added benefit for their application in the food colour industry. The presence of negatively charged functional groups such as sulphates, phosphates, carboxylic acids, phenols and alcohols on the surface of the algae makes the algae to be best suited for the bio sorption process. The presence of negatively charged functional group senable them to attract the positive charged cationic dyeslike crystal violet, methylene blue and toxic heavy metals like $\mathrm{Cd}^{2+}, \mathrm{Pb}^{2+}, \mathrm{As}^{2+}, \mathrm{Hg}^{2+}, \mathrm{Cr}^{+6}$ and $\mathrm{Ti}^{40-43}$ Hence, the algaecan be employed in the dye decolorization process and sewage treatment sector. Hence, the Gracilaria corticata are the nature's gift to mankind.

\section{ACKNOWLEDGEMENT}

The authors sincerely thank Vels Institute of Science, Technology and Advanced Studies management for completing the research work successfully. The authors also thank Dr. M. Ganesan, Senior Scientist, CSIR-CSMCRI, Mandapam, Ramanathapuram district for identifying and authenticating the algae.

\section{CONFLICT OF INTEREST}

No conflict of interests declared from the author's side.

\section{ABBREVIATIONS}

GC-MS: Gas chromatography-mass spectrometry, CSIR-CSMCRI: Central Salt Marine Chemical Research Institute, SIF: Sophisticated instru- 
mentation facility, NMR: Nuclear magnetic resonance, NIST: National institute of standards and technology-2008, mL: Millilitre, min: minute, sec: second, Da: Daltons.

\section{REFERENCES}

1. Bhatnagar I, Kim SK. Immense essence of excellence: marine microbial bioactive compounds. Mar Drugs. 2010;8(10):2673-701.

2. Deepa S, Bhuvana B, Hemamalini S, Janet C, Kumar S. Therapeutic potential and pharmacological significance of the marine algae Gracilaria corticata. Pharmaceutical and Biological Evaluations. 2017;4(2):68-72.

3. Babuselvam M, Ravikumar S. Screening of Male Anti-Fertility Compounds from Marine Seaweed Macro Algae. Division of Marine Microbiology and Medicine, ManonmaniamSundaranar University: Rajakkamangalam, India. 1993;1-4

4. Smit AJ. Medicinal and pharmaceutical uses of seaweed natural products: a review. J Applphycol. 2004;16(4):245-62.

5. Cárcamo PF, Garay-Flühmann R, Squeo FA, Gaymer CF. Using stakeholders' perspective of ecosystem services and biodiversity features to plan a marine protected danarea. Environ Sci Policy. 2014;40:116-31.

6. Premila JC, Raviraja NS, Sridhar KR. Antimicrobial activity of some marine algae of south-west coast of India. Indian J Mar Sci. 1996;26(2):74-9.

7. Deepa S, Bhuvana B, Hemamalini S, Janet C, Kumar S. Therapeutic potential and pharmacological significance of the marine algae Gracilaria corticata. Pharm Biol Eval. 2017;4(2):68-72.

8. DeAlmeida CL, Falcão DS, Lima DM, Gedson R, Montenegro DA, Lira NS, et al. Bioactivities from marine algae of the genus Gracilaria. Int $\mathrm{J}$ of Mol Sci. 2011;12(7):4550-73.

9. Paniagua-Michel J, Capa-Robles W, Olmos-Soto J, Gutierrez-Millan LE. The carotenogenesis pathway via the isoprenoid- $\beta$-carotene interference approach in a new strain of Dunaliellasalina isolated from Baja California Mexico. Mar Drugs. 2009:10:7(1):45-56

10. Cen-Pacheco F, Nordström L, Souto ML, Martín MN, Fernández JJ, Daranas AH. Studies on polyethers produced by red algae. Mari Drugs. 2010;8(4):1178-88.

11. Klisch M, Häder D. Mycosporine-like amino acids and marine toxins-The common and the different. Mar Drugs. 2008;6(2):147-63.

12. Pallela R, Na-Young Y, Kim SK. Anti-photoaging and photoprotective compounds derived from marine organisms. Mar Drugs. 2010;8(2):1189-202.

13. D'Ayala G, Malinconico M, Laurienzo P. Marine derived polysaccharides for biomedical applications: chemical modification approaches. Molecules. 2008;13(9):2069-106.

14. Kellmann R, Stüken A, Orr RJ, Svendsen HM, Jakobsen KS. Biosynthesis and molecular genetics of polyketides in marine dinoflagellates. Mar Drugs. 2010;8(4):1011-48

15. DeSouza ÉT, DeLira DP, DeQueiroz AC, DaSilva DJC, DeAquino AB, Campessato MEA et al. The antinociceptive and anti-inflammatory activities of caulerpin a bisindole alkaloid isolated from seaweeds of the genus Caulerpa. Mar Drugs. 2009;7(4):689-704.

16. Güven KC, Percot A, Sezik E. Alkaloids in marine algae. Mar Drugs. 2010;8(2):269-84.

17. Cabrita MT, Vale C, Rauter AP. Halogenated compounds from marine algae. Mar Drugs. 2010;8(8):2301-17.

18. LaBarre S, Potin P, Leblanc $C$, Delage L. The halogenated metabolism of brown algae (Phaeophyta), its biological importance and its environmental significance. Mar Drugs. 2010;8(4):988-1010.

19. Ianora A, Boersma M, Casotti R, Fontana A, Harder J, Hoffmann F, et al. New trends in marine chemical ecology. Estuaries Coasts. 2006;29(4):531-51.

20. Sermakkani M, Thangapandian V. GC-MS analysis of Cassia italica leaf methanol extract. Asian J Pharm Clin Res. 2012;5(2):90-4.

21. Elezabeth VD, Arumugam S. GC-MS analysis of ethanol extract of Cyperusrotundus leaves. Int J Curr Biotechnol. 2014;2(1):19-23.
22. Zheng CJ, Yoo JS, Lee TG, Cho HY, Kim YH, Kim WG. Fatty acid synthesis is a target for antibacterial activity of unsaturated fatty acids. FEBS lett. 2005;579(23):5157-62

23. Pinto ME, Araujo SG, Morais MI, Sá NP, Lima CM, Rosa CA, et al. Antifungal and antioxidant activity of fatty acid methyl esters from vegetable oils. An Acad Bras Cienc. 2017;89(3):1671-81.

24. Sahin N, Kula I, Erdogan Y. Investigation of antimicrobial activities of nonanoic acid derivatives. Fresenius Environ Bull. 2006;15(2):141-3.

25. Orhan IE, Özçelik B, Sener B. Evaluation of antibacterial, antifungal, antiviral and antioxidant potentials of some edible oils and their fatty acid profiles. Turk J Biol. 2011;35(2):251-8.

26. Walters D, Raynor L, Mitchell A, Walker R, Walker K. Antifungal activities of four fatty acids against plant pathogenic fungi. Mycopathologia. 2004;157(1):87-90.

27. El-Din SM, El-Ahwany AM. Bioactivity and phytochemical constituents of marine red seaweeds (Janiarubens, Corallina mediterranea and Pterocladiacapillacea). Journal of Taibah University for Science. 2016;10(4):471-84.

28. Liu X, Ma Z, Zhang J, Yang L. Antifungal Compounds against Candida Infections from Traditional Chinese Medicine. Bio Med Research International. 2017;2017.

29. Geethalakshmi R, Sarada DV. Evaluation of antimicrobial and antioxidant activity of essential oil of Trianthemadecandra L. J Pharm Res. 2013;6(1):101-6.

30. Iauk L, Acquaviva R, Mastrojeni S, Amodeo A, Pugliese M, Ragusa M, et al. Antibacterial, antioxidant and hypoglycaemic effects of Thymus capitatus (L.) Hoffmanns. Et Link leaves' fractions. J Enzyme Inhibmed Chem. 2015;30(3):360-5

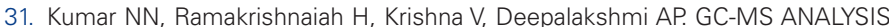
AND ANTIMICROBIAL ACTIVITY OF SEED OIL OF BROUSSONETIA PAPYRIFERA (L.) VENT. Int J Pharm Sci Res. 2015;6(9):3954-60.

32. Sermakkani M, Thangapandian V. GC-MS analysis of Cassia italica leaf methanol extract. Asian J Pharm Clin Res. 2012;5(2):90-4.

33. Agoramoorthy G, Chandrasekaran M, Venkatesalu V, Hsu MJ. Antibacterial and antifungal activities of fatty acid methyl esters of the blind-your-eye mangrove from India. Braz J Microbiol. 2007;38(4):739-42.

34. Meenambiga SS, Venkataraghavan R, Biswal RA. In silico analysis of plant phytochemicals against secreted aspartic proteinase enzyme of Candida albicans. J Appl Pharm Sci. 2018;8(11):140-50

35. Choi JS, Park NH, Hwang SY, Sohn JH, Kwak I, Cho KK, et al. The antibacterial activity of various saturated and unsaturated fatty acids against several oral pathogens. J Environ Biol. 2013;34(4):673-6

36. Farrington M, Brenwald N, Haines D, Walpole E. Resistance to desiccation and skin fatty acids in outbreak strains of methicillin-resistant Staphylococcus aureus. Journal of Medical Microbiology. 1992;36(1):56-60

37. Bergsson G, Arnfinnsson J, Steingrimsson Ó, Thormar H. In vitro killing of Candida albicans by fatty acids and monoglycerides. Antimicrob Agents Chemother 2001;45(11):3209-12.

38. Hwang JH, Hwang IS, Liu QH, Woo ER, Lee DG. (+)-Medioresinol leads to intracellular ROS accumulation and mitochondria-mediated apoptotic cell death in Candida albicans. Biochimie. 2012;94(8):1784-93.

39. Delnavazi MR, Tavakoli S, Rustaie A, Batooli H, Yassa N. Antioxidant and antibacterial activities of the essential oils and extracts of Dorema ammoniacum roots and aerial parts. Res J Pharmacogn. 2014;1(4):11-8.

40. Vijayaraghavan J, Pushpa BT, Basha SS, Jegan J. Removal of a basic dye from aqueous solution by Gracilaria corticata. J Environ Biotechnol Res. 2015;1(1):30-6

41. Vijayaraghavan J, Bhagavathi PT, Sardhar BSJ, Jegan J. Isotherm, kinetics and mechanistic studies of methylene blue biosorption onto red seaweed Gracilaria corticata. Desalin Water Treat. 2016;57(29):13540-8.

42. Nasab SM, Naji A, Yousefzadi M. Kinetic and equilibrium studies on biosorption of cadmium (II) from aqueous solution by Gracilaria corticata and agar extraction algal waste. J Appl Phycol. 2017;29(4):2107-16.

43. Tamilselvan N, Hemachandran J, Thirumalai T, Sharma CV, Kannabiran K, David E. Biosorption of heavy metals from aqueous solution by Gracilaria corticata varcartecala and Grateloupialithophila. J Coastal Life Med. 2013;1(2):102-7.

\section{GRAPHICAL ABSTRACT}

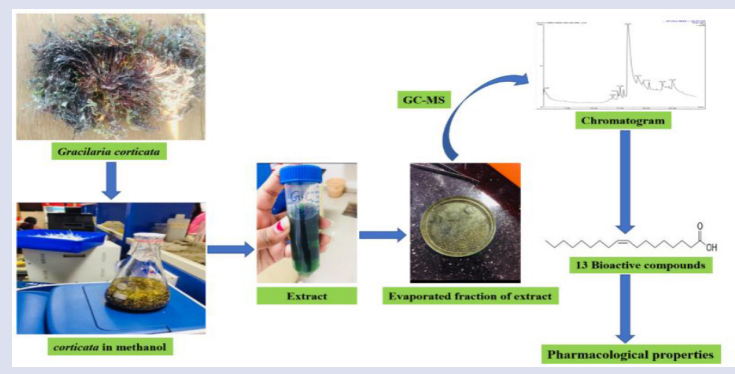

\section{SUMMARY}

- The main motive of the work was to reveal the various bioactive compounds from red macroalgae Gracilaria corticata. The methanolic extracts of Gracilaria corticata was analysed using the GC-MS (Perkin Elmer, Clarus 680). The analysis revealed the presence of thirteen bioactive compounds. The present work reported the thirteen compounds along with their potential activities like antibacterial, antifungal, antioxidant, antiparasitic etc. Hence, Gracilaria corticata can be used in the drug discovery and development sector towards the development of novel therapeutics. 


\section{ABOUT AUTHORS}

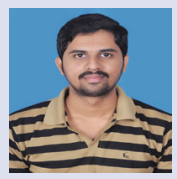

Venkataraghavan Ragunathan, his field of interest relies on Environmental biotechnology, Molecular biology and genetics, phycology, polymers, phycocolloids and Bioenergy. He has completed project at CSIR-CSMCRI on Hypnea valentiae cultivation and hydrocolloid polysaccharides extraction. He have published four papers in various International and National journals.

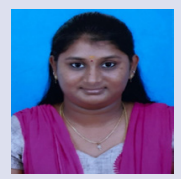

Jayashree Pandurangan, final year B. Tech Biotechnologist possessing immense research interest in the filed of algology, molecular biology, biopolymers and bioplastics. She has published three paper during my undergraduate programme.

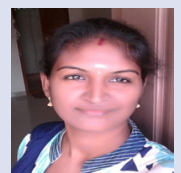

Thiruchelvi Ramakrishnan, is an assistant Professor with 2 years' experiences in the field of Biotechnology. Dedicated educationalist and established part of latest cutting-edge technology with keen interest on Biotechnology that benefit to the society. Innovative teacher devoted to learning and achieving global competence. Passionate about teaching and have trained many young students in the field of marine Biotechnology, Natural Product Research and Drug Discovery from Macroalgae. Skilled in scientific writing covering the following aspects: Proposal submission, research articles suitable for national and international publications, drafting, proof reading and editing research thesis, newsletters, etc

Cite this article: Ragunathan V, Pandurangan J, Ramakrishnan T. Gas Chromatography-Mass spectrometry Analysis of Methanol Extracts from Marine Red Seaweed Gracilaria corticata. Pharmacog J. 2019;11(3):547-54. 